Nataliia Letunovska,

Ph.D., Sumy State University, Ukraine

(iD) ORCID ID, 0000-0001-8207-9178

email: n.letunovska@gmail.com

Aleksy Kwilinski,

Dr.Sc., The London Academy of Science and Business, United Kingdom

ORCID ID: 0000-0001-6318-4001

email: a.kwilinski@london-asb.co.uk

Bozena Kaminska,

Ph.D., The London Academy of Science and Business, United Kingdom

ORCID ID: 0000-0002-0654-870X

email: bozenaka@gmail.com

Correspondence author: n.letunovska@gmail.com

\title{
SCIENTIFIC RESEARCH IN THE HEALTH TOURISM MARKET: A SYSTEMATIC LITERATURE REVIEW
}

Abstract. The authors pay attention to bibliographic analysis in the field of health tourism. The primary purpose of the study is to find out which countries' works predominate in scientific circles, and which nationalities have the most significant influence in the scientific community in terms of the number and content of their research. In particular, they do an in-depth analysis of researches in health tourism marketing. The authors put forward hypotheses about the growing popularity of marketing research in this category, which they confirmed during their investigation. Besides, the study concluded that most articles in health tourism marketing are analytical, systematizing data from secondary sources. The authors constructed a visualized representation of the relationships of important concepts, namely the services market, tourism market, health, and medical tourism. The total number of articles and cited articles in the authoritative world scientometric databases Scopus and Web of Science have been performed. TOP authors and countries that make the most considerable contribution to the number of studies of the selected category are selected. The main keywords used in articles on health tourism are systematized, among which it is possible to single out a cluster of purely marketing concepts. The authors constructed a PRISMA chart to cut off less relevant articles and select those related to the marketing aspects of the health services market. The inferences made it possible to form a detailed classification of health tourism by identifying key categories and the role of components of the tourist offer in them. The author's research will be useful for further research in health tourism, as it provides a basis for some of the works already analyzed and describes the tools for bibliographic analysis of literature sources.

Keywords: health tourism market, marketing in health tourism, medical tourism, preventive tourism, PRISMA diagram.

Introduction. The development of tourism characterizes the economy of many countries. For such countries, tourism has become a kind of philosophy: the philosophy of vision of their country, region, city (Tielietov et al., 2014). Tourism ensures the development of the country's destinations, promotes the employment of its citizens, the establishment of business partnerships, raising national social living standards, improving infrastructure, and more (Pimonenko et al., 2018). Tourist travel is at the peak of popularity among Generation Z and millennials. In 2019, the sphere of international tourism showed growth rates - by $4 \%$ compared to 2018 . Although in 2020 , the world is experiencing a time of pandemic caused by COVID-19, according to optimistic forecasts, this level should remain with the number of travelers at 1.5 billion people. Table 1 shows indicators of the market of tourist services among the leading countries in terms of the number of travelers.

Cite as: Letunovska, N., Kwilinski, A., \& Kaminska, B. (2020). Scientific Research in the Health Tourism Market: A Systematic Literature Review. Health Economics and Management Review, 1, 8-19. http://doi.org/10.21272/hem.2020.1-01 
N., Letunovska, A., Kwilinski, B., Kaminska. Scientific Research in the Health Tourism Market: A Systematic Literature Review.

Table 1. Statistics of the tourism industry in the world

\begin{tabular}{llll}
\hline Country & $\begin{array}{l}\text { Number } \\
\text { visitors, } \\
\text { people }\end{array}$ & $\begin{array}{l}\text { of } \\
\text { oflion }\end{array}$ & $\begin{array}{l}\text { Average percentage } \\
\text { of revenues from } \\
\text { tourism in } \begin{array}{l}\text { Average employment } \\
\text { country's GDP, } \%\end{array}\end{array}$ \\
\hline France & 89 & 9.7 & 2.9 \\
\hline Spain & 83 & 12 & 3.0 \\
\hline USA & 80 & 2.8 & 7.8 \\
\hline China & 63 & 11.05 & 28.25 \\
\hline Italy & 62 & 13.3 & 3.5 \\
\hline Turkey & 46 & 12.1 & 2.16 \\
\hline Mexico & 41 & 8.7 & 4.7 \\
\hline Germany & 39 & 10.4 & 3.1 \\
\hline Thailand & 38 & 21.6 & 2.5 \\
\hline United Kingdom & 36 & 7.2 & 1.7 \\
\hline
\end{tabular}

Sources: developed by the authors on the basis of Statista.

The alternative form of tourism is health tourism. It differs significantly from other types of tourism, especially entertainment. Its development requires specific infrastructure, staff, understanding of the target audience, specialized marketing, etc. International tourism statistics show that the purpose of travel for health is among the main reasons for people to visit other regions and countries, Fig. 1. Moreover, if for statistics, the world is dominated by travel for leisure purposes, then for the Middle East (Iraq, Lebanon, Israel, Saudi Arabia, Qatar, Oman, etc.) it is dominated by travel to visit relatives and friends, religious and importantly, wellness.

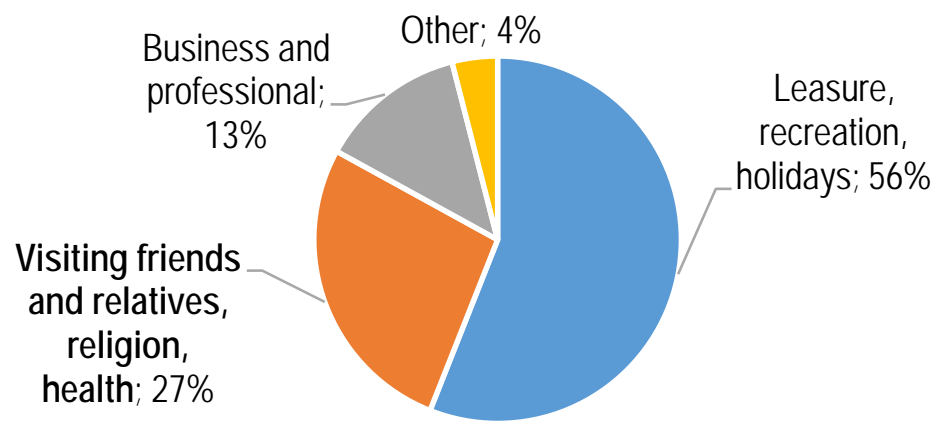

Figure 1. Reasons to visit other regions and countries

Sources: developed by the authors on the basis of (UNWTO, 2019).

When a person travels abroad to a country of residence for medical procedures or treatment, then she/he becomes a consumer of medical tourism services. Moreover, in this case, this type of service belongs to the field of tourism because it is assumed that such clients often stay in the country of treatment before and after surgery, procedures, etc. for travel and recreation (Mohsen et al., 2018). Also, many countries have health resorts that provide recreation in a healthy region to prevent disease and prolong life. Therefore, with the growing popularity of the concept of healthy living, which will only gain momentum 

Review.

after the effects of the COVID-19 pandemic in the world, many customers of travel services will consider the «healthy parameters» of their travel abroad or in domestic tourism. The pandemic has made its adjustments in the motivation to travel for treatment. Thus, according to research, medical travelers will select destinations that have managed COVID-19 better than others. They will be more focused on the safety of the healthcare provider related to COVID-19 (Pollard, 2020). So, these features must be taken into account by market operators.

From 2018 to 2019, the global medical tourism sector grew by 17\%. In 2019, the volume of the medical tourism market one estimated at 65-80 billion dollars USA (Globalmedik, 2020). In the dynamics from the end of 2019 to 2025, it should be more than $12 \%$ of the total average annual growth rate. The turnover of medical tourism in 2019 amounted to about 45 million trips per year (Knoema, 2020). If earlier, the most popular directions of medical tourism in the world were the countries from Table 1, today, such countries as India, Malaysia, Singapore, South Korea have developed their health care system so much that they are already able to attract millions of medical tourists a year. From these positions, it is interesting to explore how the emphasis on scientists from different countries has changed over the years. Therefore, the initial goal of the study is to find out which works of authors from which countries predominate in scientific circles, which nationalities have the most significant influence in the scientific community in terms of the number and content of their research.

Literature Review. People use medical tourism opportunities for various reasons: some cannot afford treatment in their own country, others cannot wait to receive national medical care, specific treatments are not available in the countries where such people live, or, for example, people seek medical care at home and abroad (Valentova et al., 2016). Scientists from different countries considered the category of medical tourism in different aspects. The authors are interested in bibliometric research, which was performed before. Thus, the paper (Smith, et al., 2011) examines medical tourism in the light of global bilateral trade with a focus on the scientific achievements of scientists under the General Agreement on Trade in Services. The authors conclude a significant gap and lack of systematic data on world trade in health services. For the most part, there are developments on the national characteristics of health services and individualized approach to customer service. The authors (Ferdosi et al., 2013) analyzed articles of various types. They searched for definitions of medical tourism, and how authors of different nationalities describe its advantages and disadvantages. Certain aspects of the formation of tourist motivation and how it was studied in analytical articles are also considered. In (Hanefeld et al., 2015), along with research on the growing popularity of health tourism in the world and the total number of scientific papers in this field, the authors identify several gaps in knowledge about this tourism, among which they note the lack of information about patients' background, limited marketing insights into why some patients travel and others do not, unformed views on the interaction of the tourism sector with the medical sector. The authors (Hadian et al., 2019) conducted a systematic review of the economic literature on health tourism with the inclusion in the analysis of various scientometric databases. In (Wolfenden, 2016), the bibliographic review is adopted as a critical research method to find other research areas and group the available best recommendations in the field of medical services, in particular in the field of health tourism. (Fanelli et al., 2020) use a systematic literature review to investigate health care issues in low- and middle-income countries. They conclude that this method helps to classify the causes and consequences of different events in the field of medical services and to form the right ideas for further research in the relevant field.

There are also developments concerning the literary review of scientific works in the field of health tourism in the complex dissertation researches of the Ukrainian authors. The dissertation (Malimon, 2013) considers the issue of health tourism through the prism of prospects for the development of innovative areas of tourism in the works of domestic and foreign scientists. Simultaneously, based on the results of the systematization of scientific research, it concludes that there are insufficient achievements on the principles of the formation and development of regional tourism markets in Ukraine. In the dissertation 
research (Gaponova, 2019) focusing on the market of medical services and a particular segment - medical tourism, the author notes a small number of studies on the prospects of the market of medical services and the focus of researchers only on certain aspects without an in-depth study of such niche sphere. The dissertation research (Didenko, 2019) is unique in its work on the literature review, which combines an analysis of the parameters of competitiveness of tourism businesses and the region as a whole.

Besides, government organizations in many countries (World Health Organization, the American Medical Association, Indian Institute of Tourism and Travel Management) and consulting companies (e.g., Deloitte) conducted and continue to research to determine the impact of health tourism on the national economies of the world. In Ukraine, the Ukrainian Association of Medical Tourism, as a member of the Global Healthcare Travel Council, is actively involved in health tourism.

Methodology and research methods. To achieve the goals of the study, the authors conducted a systematic bibliographic analysis of scientific sources, namely articles in Scopus and Web of Science databases. They used built-in Scopus analytics for source analysis and software for bibliographic analysis of VOS Viewer. Additionally, they proposed to use a PRISMA diagram for the gradual selection of the necessary articles for analysis in the selected field of study.

The hypothesis of the investigation. The authors identified the following hypotheses of the study:

$\mathrm{H} 1$ : Most of the articles on health tourism research presented in Scopus and/or Web of Science databases are empirical.

$\mathrm{H} 2$ : Research in the field of marketing in recent years (2015-2020) is gaining popularity among scientists engaged in development in the field of health tourism.

Results. Before starting the literary analysis, it is necessary to distinguish between concepts in the field of health tourism clearly. The concept of health tourism is a generalization, which can be further classified depending on the content of the tourist offer of travel, destination, and direct medical services and services to recover the human body (Fig. 2).

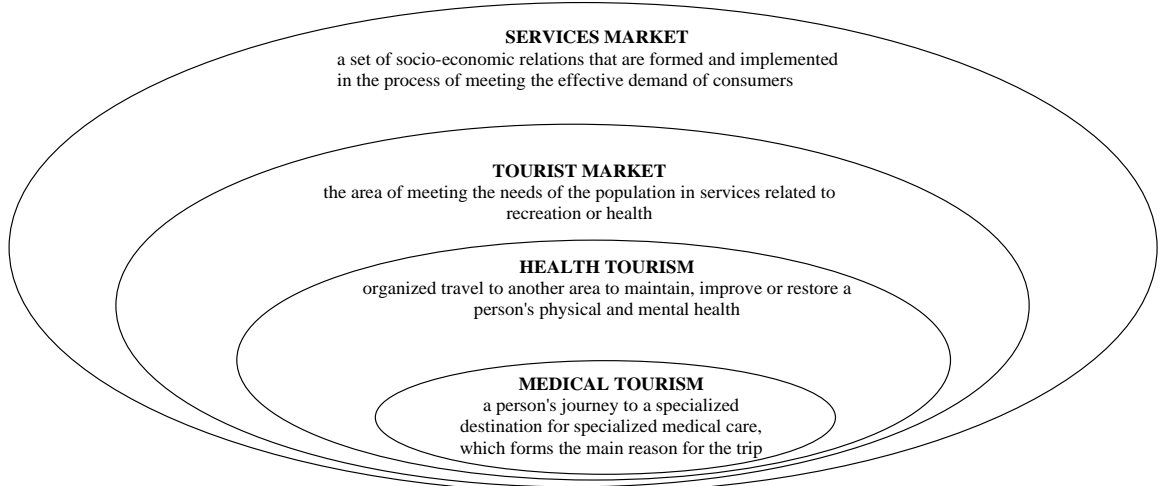

Figure 2. The shell of research concepts relations

Sources: developed by the authors.

Scopus and Web of Science databases were selected as sources to form a database of articles for analysis. The Scopus Journals title list contains over 39,743 titles, including over 25,000 active titles and over 14,558 inactive titles (mostly predecessors of the active titles) (Scopus, 2020). This database is quite a complete set of scientific papers in the field of health tourism. However, the paper (Chughtai et al., 2017) noted that the Web of Science database contains more than 12,000 peer-reviewed scientific journals. Due to the excellent content of these leading scientific databases of publications, they were selected as a 
general set of articles. One chose the keywords «medical tourism», «health tourism» and «trade in health services» as the primary sample for analysis within the author's research. The study considered only articles written in English. The analysis is limited to articles no later than 2015. The type of documents selected for analysis is just an article. The authors did not choose such categories as «review», «book chapter», "conference paper», etc., because they are interested in peer-reviewed publications, which are always scientific journals included in the selected databases. Publications in physics and astronomy, biochemistry, engineering, computer science, pharmacology, mathematics, etc. have been removed from the analysis. Figures 3 and 4 present the total number of articles in databases.

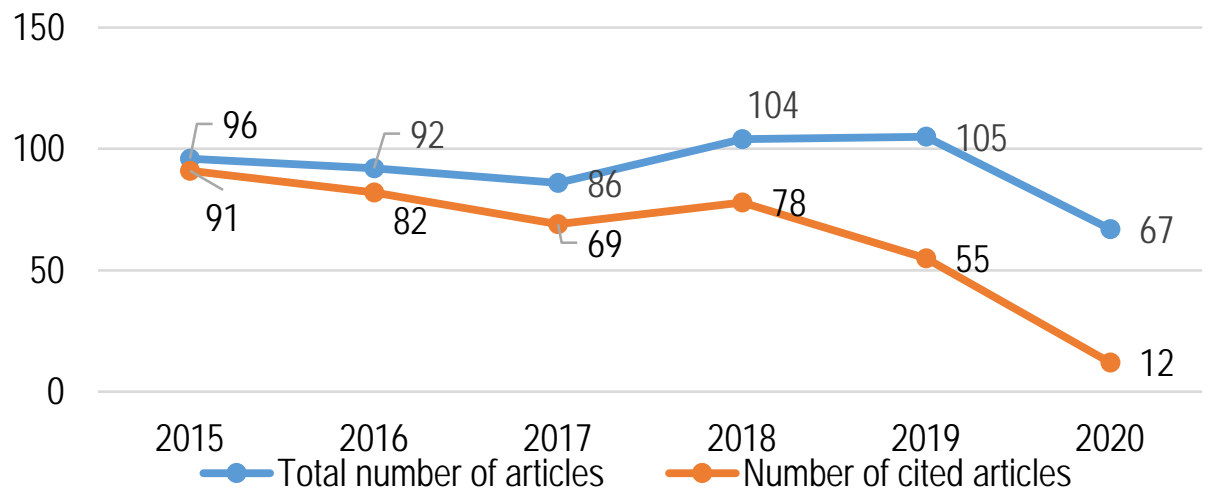

Figure 3. The number of articles on a research topic in the Scopus database in 2015-2020 Sources: developed by the authors.

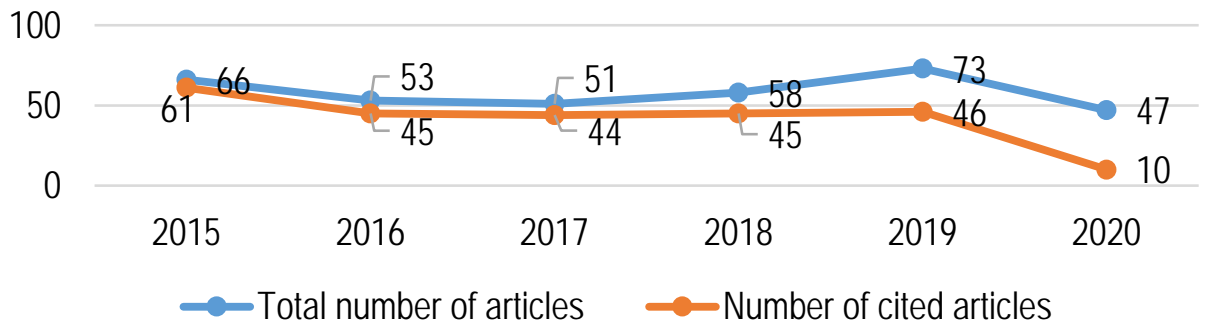

Figure 4. Number of articles on a research topic in the Web of Science database in 2015-2020 Sources: developed by the authors.

Analysis of articles and their citations in both databases showed that with more articles on the subject of research in the Scopus database, which is not surprising given the more generous coverage of the number of journals in this database, the percentage of cited articles in the Web of Science database is higher. The content of the articles from the Scopus base with the highest citations was studied. Thus, the article (Heesup et al, 2015), published in 2015, cited 180 times, is devoted to various medical tourism services that contribute to customer retention. In 2016, the most cited article was published in world-ofmouth marketing and how it affects the formation of trust in medical tourism market operators (Abubakar et al., 2016). The 2018 article deals with analyzing keywords to identify trends in future research (la HozCorrea et al., 2018). The most cited article in 2019 examines the impact of medical tourism on the economic growth of the markets of countries that receive and send tourists. The most cited 2020 article 
N., Letunovska, A., Kwilinski, B., Kaminska. Scientific Research in the Health Tourism Market: A Systematic Literature Review.

(11 times) defines health tourism and «healthy destination» as a territorial tourist complex, which includes specialized infrastructure often adjacent to resorts and reveals the consumption goals of this type of tourism and the factors that shape tourist satisfaction.

The built-in analysis in the Scopus database made it possible to single out the prominent authors whose works correspond to the subject of the search (Fig. 5) and single out the national affiliation of the works (Fig. 6)

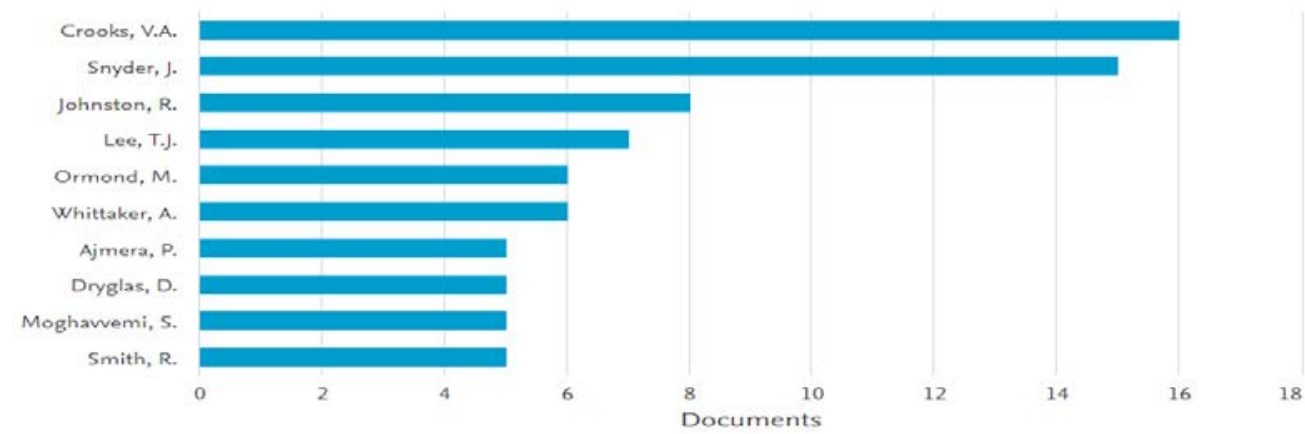

Figure 5. Top 10 authors whose works are devoted to health tourism (from the Scopus database) Sources: developed by the authors.

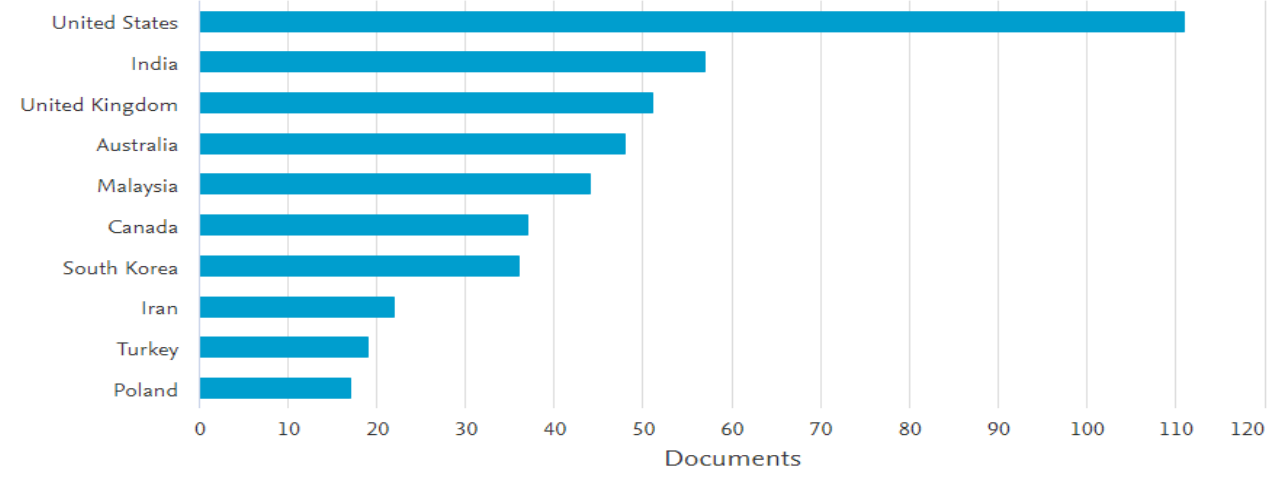

Figure 6. Top 10 countries whose authors studied the categories in the field of health tourism

Sources: developed by the authors. (from the Scopus database)

Since the Web of Science database does not have a built-in tool for analyzing articles, the analysis of the authors and the nationality of the articles was done using the program VOS Viewer (Fig. 7-8). In general, in both cases, the authors and the countries are repeated for both bases. The leading countries, the authors of which pay the most attention to the study of various aspects of health tourism (innovation, economic, marketing, etc.), are the United States, India, United Kingdom, Australia, Malaysia, Canada, South Korea, Iran, Turkey, Poland. Thus, the authors from these countries form the general worldview and trends in the studied field. 


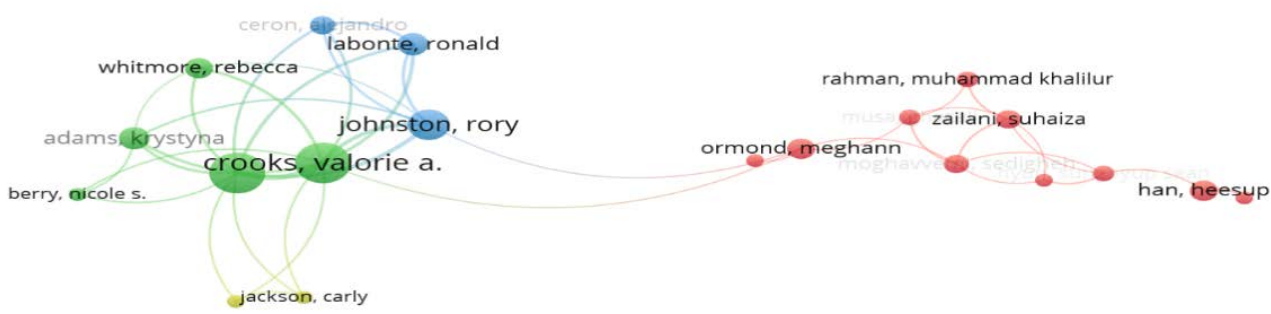

Figure 7. The main authors of articles on health tourism in the Web of Science database Sources: developed by the authors using VOS Viewer software.

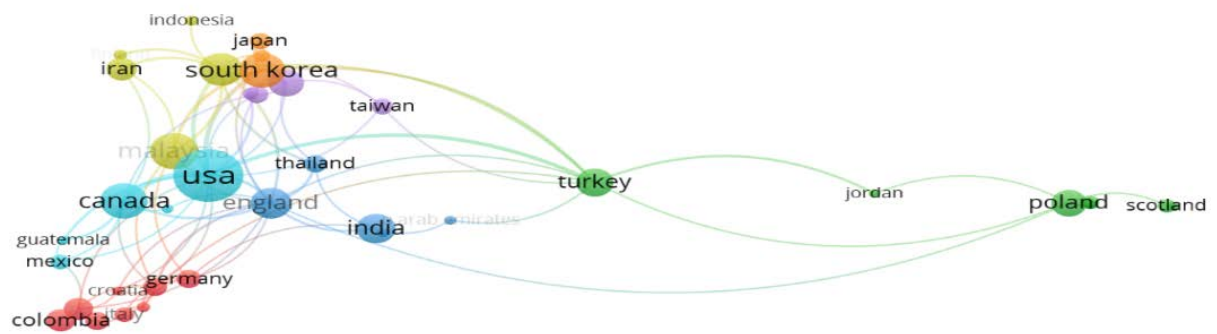

Figure 8. Affiliation of articles on health tourism by country in the Web of Science database Sources: developed by the authors using VOS Viewer software.

From the analysis of Figure 9 , it is evident that the topics of marketing, consumption, and motivation are quite popular in the research of scientists from different countries. It determined the next steps in the study of sources - focusing on articles in marketing.

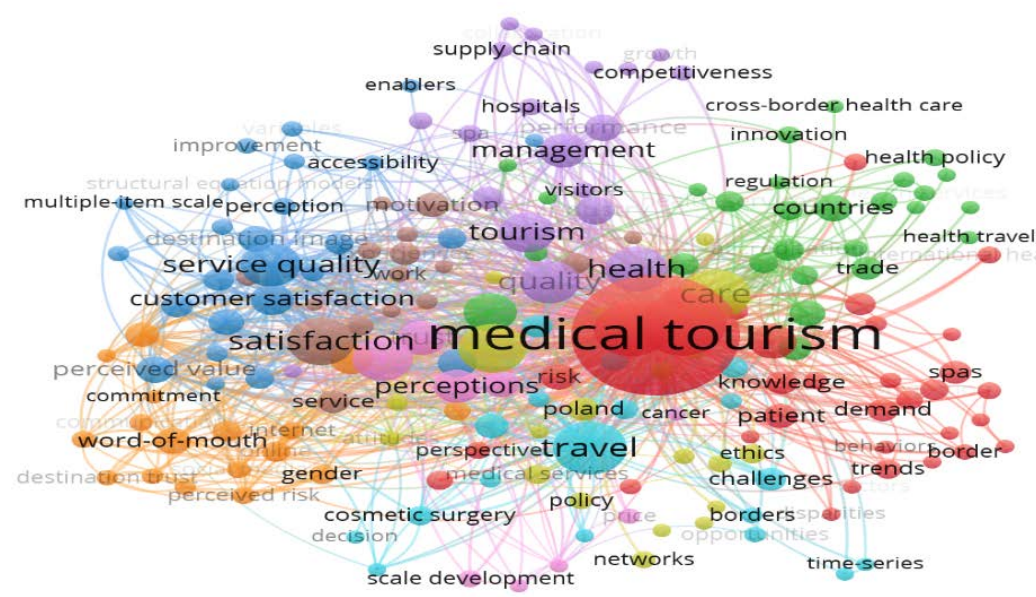

Figure 9. Analysis of articles devoted to research in health tourism by keywords Sources: developed by the authors using VOS Viewer software. 
N., Letunovska, A., Kwilinski, B., Kaminska. Scientific Research in the Health Tourism Market: A Systematic Literature Review.

Typical research topics in health tourism are the analysis of destinations, risks, and opportunities for this type of tourism in a particular country or group of countries; cost issues, issues of quality of health services; behavior and experience of using tourist services of this type, motivation for their consumption; models of decision-making on the choice of health tourism services; the analysis of market success factors and taking into account the criteria for building a successful marketing campaign to promote health tourism services.

In the analysis of publications, it was taken into account that, for example, such journals as Tourism Management, Entrepreneurship and Sustainability Issues, Sustainability, Journal of Travel Research, Journal of Destination Marketing and Management, Economic Modeling, and others included simultaneously in both databases. Therefore, when constructing the PRISMA diagram, duplicate articles were taken into account once (Fig. 10).

An in-depth analysis of articles on marketing in health tourism showed that most articles are analytical (Fig. 11). In total, the authors identified three types of articles: tourism);

- review article (general, to a greater extent is an introduction to understanding the concept of health

- analytical (based on secondary research, including marketing, offering new insights and ideas for development in health tourism);

- empirical (containing primary data (qualitative and / or quantitative, collected by the authors during interviews, surveys, observations, etc., and analyzed).

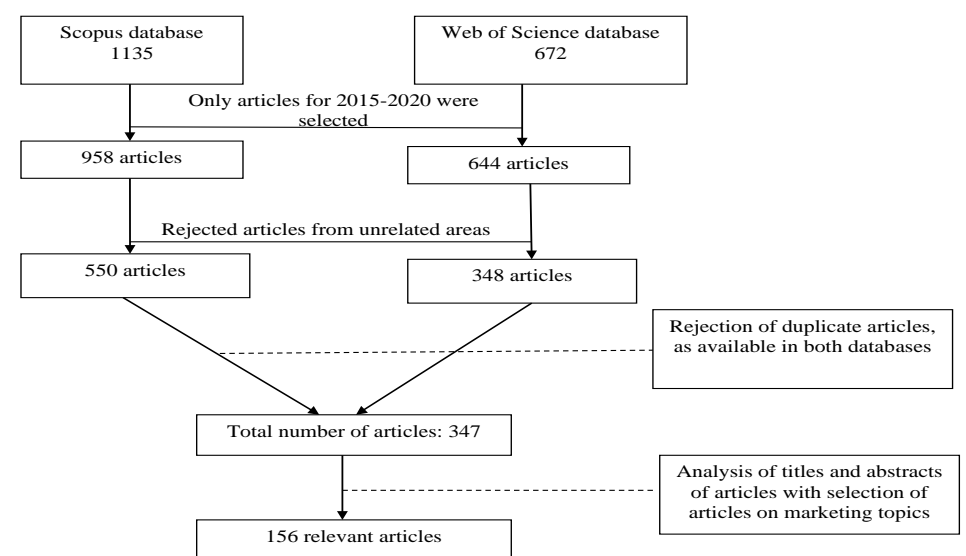

Figure 10. PRISMA flow diagram for a literature review of the studied categories in the sphere of health tourism

Sources: developed by the authors.

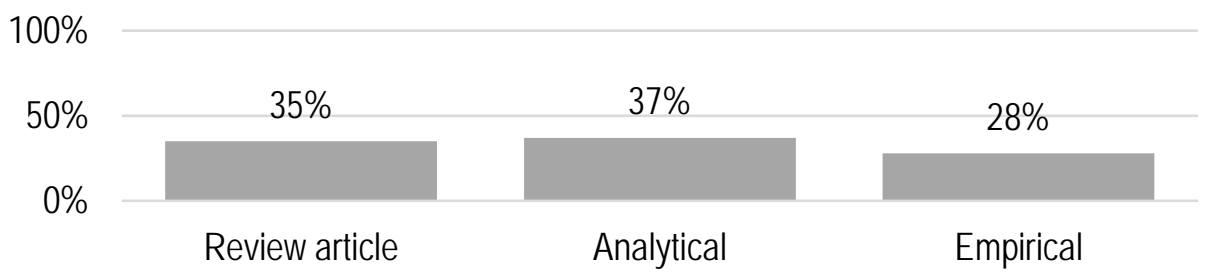

Figure 11. Breakdown of the sample by the type of article

Sources: developed by the authors. 
The authors selected the journals with the largest number of publications by the studied category (Table 2). It is noteworthy that from this sample, there are two purely marketing journals (Journal of Travel and Tourism Marketing, International Journal of Pharmaceutical and Healthcare Marketing), which suggests that the topic of health tourism marketing is entrenched in the scientific world among the journals of authoritative scientometric bases.

Table 2. Journal-wise publication breakdown table

\begin{tabular}{|c|c|c|c|c|c|c|c|c|}
\hline \multirow{2}{*}{ Source } & \multirow{2}{*}{ Quartile } & \multicolumn{6}{|c|}{ Publication year } & \multirow{2}{*}{ Total } \\
\hline & & 2015 & 2016 & 2017 & 2018 & 2019 & 2020 & \\
\hline $\begin{array}{l}\text { Social Science } \\
\text { Medicine }\end{array}$ & $\begin{array}{l}\text { Q1 (Health (social } \\
\text { science) }\end{array}$ & 13 & & 1 & 1 & 1 & & 16 \\
\hline $\begin{array}{c}\text { Tourism } \\
\text { Management }\end{array}$ & Q1 (Development) & 3 & 1 & 3 & 5 & 4 & & 16 \\
\hline $\begin{array}{l}\text { Current Issues in } \\
\text { Tourism }\end{array}$ & $\begin{array}{l}\text { Q1 (Geography, } \\
\text { Planning and } \\
\text { Development) }\end{array}$ & & 3 & 2 & 3 & 2 & 2 & 12 \\
\hline $\begin{array}{l}\text { Journal of Travel } \\
\text { and Tourism } \\
\text { Marketing }\end{array}$ & Q1 (Marketing) & 2 & 2 & 2 & & 4 & 2 & 12 \\
\hline Sustainability & $\begin{array}{c}\text { Q2 (Energy } \\
\text { Engineering and } \\
\text { Power Technology) }\end{array}$ & & 1 & & 1 & 6 & 4 & 12 \\
\hline $\begin{array}{l}\text { International } \\
\text { Journal of } \\
\text { Environmental } \\
\text { Research and } \\
\text { Public Health }\end{array}$ & $\begin{array}{l}\text { Q2 (Health, } \\
\text { Toxicology and } \\
\text { Mutagenesis) }\end{array}$ & & & & 1 & 3 & 7 & 11 \\
\hline $\begin{array}{l}\text { African Journal of } \\
\text { Hospitality, Tourism } \\
\text { and Leisure }\end{array}$ & $\begin{array}{l}\text { Q3 (Geography, } \\
\text { Planning and } \\
\text { Development) }\end{array}$ & & & 2 & 2 & 5 & & 9 \\
\hline $\begin{array}{c}\text { International } \\
\text { Journal of } \\
\text { Pharmaceutical } \\
\text { and Healthcare } \\
\text { Marketing }\end{array}$ & Q3 (Health Policy) & 1 & 2 & 1 & 2 & 2 & & 8 \\
\hline $\begin{array}{c}\text { Asia Pacific Journal } \\
\text { of Tourism } \\
\text { Research }\end{array}$ & $\begin{array}{l}\text { Q1 (Geography, } \\
\text { Planning and } \\
\text { Development) }\end{array}$ & & 2 & 2 & 2 & 1 & & 7 \\
\hline $\begin{array}{c}\text { International } \\
\text { Journal of Tourism } \\
\text { Research } \\
\end{array}$ & $\begin{array}{l}\text { Q1 (Geography, } \\
\text { Planning and } \\
\text { Development) }\end{array}$ & 1 & & 2 & 2 & 1 & 1 & 7 \\
\hline \multicolumn{2}{|c|}{ Total } & 20 & 11 & 15 & 19 & 29 & 16 & 110 \\
\hline
\end{tabular}

Sources: developed by the authors.

Calculations in table 2 show that the popularity of research in health tourism is gaining momentum. Even though in 2015 there is a reasonably large number of papers, and then in 2016 it falls, we note that in 2015 such a large number of publications due to their large number in the non-economic journal (Social Science Medicine), but further this journal published a much smaller number of articles in marketing. Since 2016 , one has seen a jump to 2019 in the number of publications, which increased to 29 pieces, surpassing 
2015. The trends should continue, in particular, by the end of 2020, 16 articles on health tourism have been published and indexed. Besides, it should be borne in mind that, for example, the official page of the African Journal of Hospitality, Tourism and Leisure, which in 2019 had a large number of articles in 2020, has been inactive for a long time. That is, new articles and further indexation of certain publications by the end of the current year are expected, and, accordingly, new achievements in the field of health tourism. The analysis of quartiles of publications showed that the most authoritative in marketing with the number of publications in health tourism 12 pieces is the Journal of the United States Journal of Travel and Tourism Marketing. In 2020, it has already indexed two articles in the category of health tourism marketing. One of the articles is devoted to storytelling in medical tourism and its impact on consumer behavior and their trust in service providers. The second article of this journal, indexed in 2020, examines the issues of infrastructure in health services for tourists, namely the role of intermediaries and accommodation facilities.

The conducted research made it possible to form a classification of types of health tourism and to determine the content of its various varieties (Fig. 12). In particular, the authors distinguish between purely medical tourism, filled with medical supply, and another type of such tourism, namely preventive tourism, the purpose of which is to improve the health of tourists, but without targeted treatment of diseases.

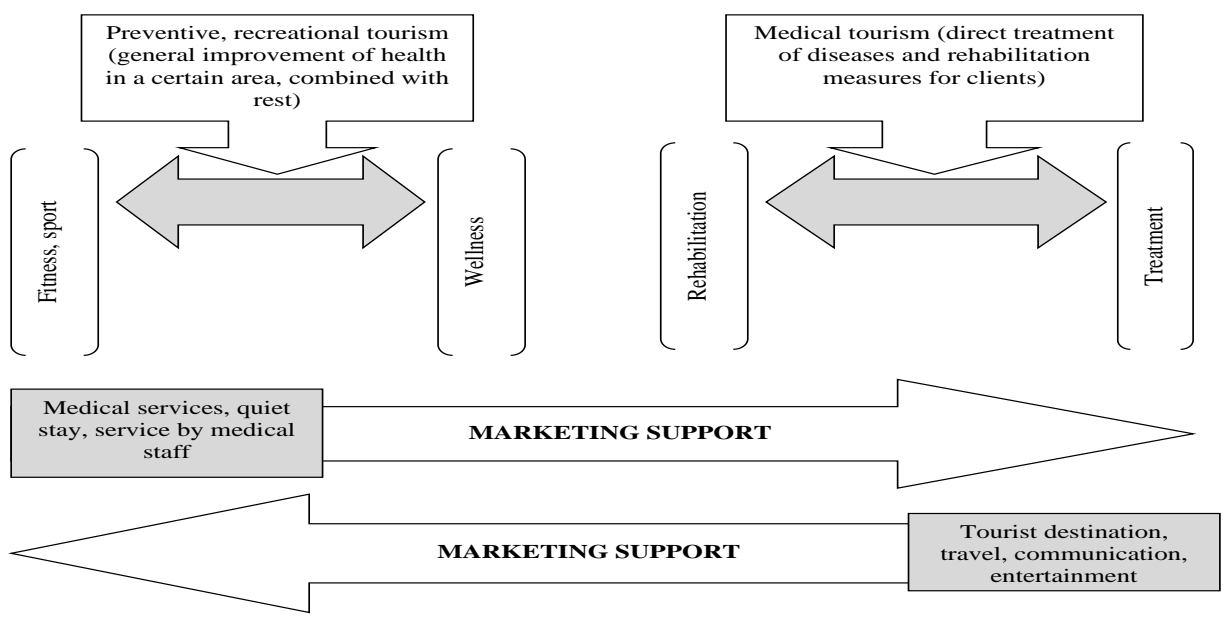

Figure 12. Classification of health tourism

Sources: developed by the authors.

Conclusions. The study confirmed one of the hypotheses, namely that the topic of marketing in the field of health tourism is gaining popularity in recent years. A sufficient number of works in this field among scientists from the United States, India, Malaysia, and other countries. The authors analyzed articles written only in English for 2015-2020 in economic areas. The second hypothesis of the study was not confirmed because most articles based on the results of calculations and detailed analysis of titles and their abstracts are analytical articles that summarize and deepen previous research or analyze available statistical information. Due to the lack of representation in the field of health tourism marketing of empirical articles, further areas of research of the authors will be with the presentation of the author's results of the market analysis. Also, for a more representative analysis of literature sources, it is advisable to use the CASP Checklist with the selection of relevant to the analysis works for their detailed analysis and use for systematization together with calculations.

Author Contributions: conceptualization, N. L. and A. K.; methodology, N. L.; software, N. L.; 
validation, N. L., A. K. and B. K.; formal analysis, N. L.; investigation, N. L.; resources, N. L.; data curation, N. L.; writing-original draft preparation, N. L. and B. K.; writing-review and editing, N. L.; visualization, A. K.; supervision, N. L.; project administration, N. L.; funding acquisition, N. L.

Funding: This research received no external funding.

\section{References}

Abubakar, A. M., \& Ilkan, M. (2016). Impact of online WOM on destination trust and intention to travel: A medical tourism perspective. Journal of Destination Marketing \& Management, 5(3), 192-201. [Google Scholar] [CrossRef]

Chughtai, S., \& Blanchet, K. (2017). Systems thinking in public health: a bibliographic contribution to a meta-narrative review. Health policy and planning, 32(4), 585-594. [Google Scholar] [CrossRef]

De la Hoz-Correa, A., Muñoz-Leiva, F., \& Bakucz, M. (2018). Past themes and future trends in medical tourism research: A coword analysis. Tourism Management, 65, 200-211. [Google Scholar] [CrossRef]

Didenko, D. F. (2019). Improvement of management mechanisms for regional tourism cluster systems. PhD dissertation abstract. Odesa. [Link]

Fanelli, S., Salvatore, F. P., De Pascale, G., \& Faccilongo, N. (2020). Insights for the Future of Health System Partnerships in Low-And Middle-Income Countries: A Systematic Literature Review. BMC health services research, 20(1), 571. [Google Scholar] [CrossRef]

Gaponova, E.O. (2019). Current trends in the world market of medical services. PhD thesis. Kharkiv [Google Scholar]

Globalmedik. How to start medical tourism abroad? Retrieved from [Link]

Hadian, M., Jabbari, A., Mousavi, S. H., \& Sheikhbardsiri, H. (2019). Medical tourism development: A systematic review of economic aspects. International Journal of Healthcare Management, 1-7. [Google Scholar] [CrossRef]

Han, H., \& Hyun, S. S. (2015). Customer retention in the medical tourism industry: Impact of quality, satisfaction, trust, and price reasonableness. Tourism Management, 46, 20-29. [Google Scholar] [CrossRef]

Hanefeld, J., Lunt, N., Smith, R., \& Horsfall, D. (2015). Why do medical tourists travel to where they do? The role of networks in determining medical travel. Social Science \& Medicine, 124, 356-363. [Google Scholar] [CrossRef]

Knoema. Key tourism indicators. Retrieved from [Link]

Malimon, V.V. (2013). Formation and development of regional markets of medical tourism in Ukraine. PhD thesis. Lutsk. [Google Scholar]

Masoud, F., Alireza, J., Mahmoud, K., \& Zahra, A. (2013). A systematic review of publications studies on medical tourism. Journal of Education and Health Promotion, 2. [Google Scholar] [CrossRef]

Mohsen, Y., Hussein, H. M., \& Mahrous, A. A. (2018). Perceived service value, customer engagement and brand loyalty in health care centres in Egypt. Marketing and management of innovations, (3), 95-108. [Google Scholar] [CrossRef].

Pimonenko, T., Lyulyov, O., Chygryn, O., \& Palienko, M. (2018). Environmental Performance Index: relation between social and economic welfare of the countries. Environmental Economics, 9(3), 1. [Google Scholar] [CrossRef]

Pollard, K. (2020). A serious impact on healthcare-related business. Retrieved from [Link]

Scopus. Content Coverage Guide (2020). Retrieved from [Link]

Smith, R., Álvarez, M. M., \& Chanda, R. (2011). Medical tourism: a review of the literature and analysis of a role for bi-lateral trade. Health policy, 103(2-3), 276-282. [Google Scholar] [CrossRef]

Tielietov, O., \& Letunovska, N. (2014). Organizational and economic mechanism of industrial enterprises social infrastructure management. Actual Problems of Economics, 10(160), 329-337. [Google Scholar]

UNWTO. International Tourism Highlights (2019). Retrieved from [Link].

Valentova, J., \& Abrham, J. (2016). Market segmentation and eliciting tourist's motives for visiting the Czech Republic. Marketing and Management of Innovations, 4, 159-168. [Google Scholar]

Wolfenden, L., Milat, A. J., Lecathelinais, C., Skelton, E., Clinton-McHarg, T., Williams, C., ... \& Yoong, S. L. (2016). A bibliographic review of public health dissemination and implementation research output and citation rates. Preventive medicine reports, 4, 441-443. [Google Scholar] [CrossRef]

H.Є. Летуновська, канд. екон. наук, Сумський державний університет (Україна);

О.С. Квілінський, доктор екон. наук, Лондонська академія науки і бізнесу (Великобританія);

Б. Каміньська, канд. екон. наук, Лондонська академія науки і бізнесу (Великобританія)

Наукові дослідження ринку оздоровчого туризму: систематичний літературний аналіз

у даному дослідження увага присвячена бібліографрічному аналізу у сфері оздоровчого туризму. Основною ціллю дослідження є з'ясування того, праці авторів з яких країн переважають в наукових колах, та які національності мають 
N., Letunovska, A., Kwilinski, B., Kaminska. Scientific Research in the Health Tourism Market: A Systematic Literature Review.

найбільший вплив у науковому товаристві за кількістю і змістовним наповненням їх досліджень. Зокрема поглиблений аналіз зроблений для досліджень у сфері маркетингу оздоровчого туризму, у т.ч. медичного туризму. Автори висунули гіпотези про зростання популярності досліджень у сфері маркетингу в означені категорії, що було підтверджено в ході виконання авторських розробок. Крім того, дослідження дало змогу зробити висновок про те, що більшість статей у сфрері маркетингу оздоровчого туризму $є$ аналітичними, що систематизують дані з вторинних джерел. Авторами побудовано візуалізоване представлення співвідношень важливих понять, а саме ринку послуг, туристичного ринку, оздоровчого та медичного туризму. Виконані підрахунки загальної кількості статей та процитованих статей у авторитетних світових наукометричних база Scopus ma Web of Science. Виокремлені TOП авторів та країн, які вносять найбільший вклад у кількість досліджень обраної категорії. Систематизовано основні ключові слова, які використовуються у статтях за тематикою оздоровчого туризму, серед яких можливо виокремити кластер суто маркетингових понять. Побудована PRISMA діаграма для відсікання менш релевантних запиту статей та відбору тих, які стосуються маркетингових аспектів на ринку оздоровчих послуд. Сукупність умовиводів дала можливість сформувати детальну класифікацію оздоровчого туризму з виокремленням ключових категорій та ролі складових туристичної пропозиції в них. Авторське дослідження буде корисним для подальших досліджень у сфеері оздоровчого туризму, оскільки дає підгрунтя в частині вже проаналізованих праць та описує інструментарій для бібліографічного аналізу літературних джерел.

Ключові слова: ринок оздоровчого туризму, маркетинг у ссері оздоровчого туризму, медичний туризм, профілактичний туризм, PRISMA діаграма.

Manuscript received: 11.08 .2020

(c) The author(s) 2020. This article is published with open access at Sumy State University. 